\title{
Professional Development of Teacher Trainers in the Higher Teacher Training College Bambili (Cameroon)
}

\author{
Lilian F. Wiysahnyuy* \\ Higher Teacher Training College, University of Bamenda, Cameroon
}

*Corresponding Author: Lilian F. Wiysahnyuy, Higher Teacher Training College, University of Bamenda, Cameroon

\begin{abstract}
Teacher trainers are key stake holders of the educational training sector. As professionals, the consistent input to enhance knowledge transfer cannot be reduced only to aptitudes acquired at initial training. Continuous professional development constitutes a crucial aspect in colleges of teacher training. In spite of this importance, the practice /policy is usually treated with levity leaving professionals not to be tuned to the dynamic demands of the teaching-learning process. It is in this context that this paper appreciates the range of professional development activities and assesses the impact they have on the teacher trainers as well as identifies the gaps and needs to the teacher trainers for a more effective professional training. The design used for this study was a case study in order to have in-depth information on the professional development activities carried out by the teacher trainers of the Higher Teacher Training College (HTTC) Bambili within the past two years. A convenient sampling technique was used to select 30 teacher trainers from a population of 72 permanent teaching staff of HTTC Bambili. The instrument used for data collection was a questionnaire which comprised both open and closed ended items. Data was analysed using descriptive statistic specifically percentages and presented in tables. The findings revealed that a majority of the respondents attended professional development programmes during the last two years although they were some variations in terms of the number of days. Some of the professional development activities which they participated in were conferences, seminars, workshops, observation visits in other classes, mentoring and teaching practice evaluation, individual research and collaborative research/net working. It was also realised that some of these activities had very high impact on the participants while others had little or no impact on them. The participants also indicated that although they had been participating in professional development programmes, they still needed more pedagogical and psychological knowledge which would enhance the teaching -learning transaction. This therefore means that professional development activities should be regular and commensurate to the needs of the teacher trainers.
\end{abstract}

Keywords: Professional development, Teacher Trainers/ Educators

\section{INTRODUCTION AND LITERATURE}

A cursory look at the student assessment reports on the pedagogy and professional output of teacher trainers at the end of each semester expose great concerns of the standards of teaching-learning values. Furthermore, informal interaction with students as a pedagogic animator in the department of Science of Education as well as discussions with a cross section of teacher trainers who were recruited without prior knowledge of educational science show inevitable lapses that might have a detrimental effect on the quality of graduates. These consistent professional lapses suggest a need for a rigorous professional development policy to train prospective teachers socialized in states-of-arts methods and techniques of teaching. It is in this premise that the question of professional development in one of Cameroon's main teacher training colleges becomes imperative.

The quality of formal education largely depends among other factors on the quality of training given to teachers in the training schools. In recent years, they have been calls on equal opportunities and quality education for all and at all levels in order to achieve quality learning outcomes (UNESCO 2000). It is understood that factors that facilitate formal education or learning ranges from curriculum to the school environment but note should be taken that the competence of the teacher matters a lot as far as the teaching -learning process is concerned. According to Dilshad (2010) the quality of teachers depends on the qualification of teachers and quality of pre- service and in-service teacher education they have acquired. This implies that the competence is based on how effective the teacher was 
trained in the training school. The competence of the teacher trainers largely depends on the professional development activities they undertake as they train the student teachers. Although teacher trainers are of different categories, it is very important for every teacher trainer to be involved in activities that can enhance their professional development. According to Vobrecht (2003), teachers professional development involves learning and teaching in higher education, curriculum studies, staff development, assessment and evaluation, academic literacy, postgraduate supervision and peer group learning. This indicates that professional development entails several activities. Musaazi (1982) on his part sees teachers' professional development as the provision made by education authorities to improve on the performance of teachers from initial employment to retirement. In order to achieve this, he lays emphasis on the development of an in-service programme based on the professional needs of the different categories of teachers in the university system like workshops, seminars, refresher courses, exchange teaching, professional writing, staff meetings, post graduate studies at university and participation in the evaluation of school programmes. According to Palinscar (1998), professional development of higher education practitioners is viewed as an intellectual activity where teachers play a participatory role and engage in reflective practice to gain insight on teaching problems in the classroom. He notes that the term professional development in a broader sense refers to the development of being in his or her professional role.

Teachers professional development is associated with professional growth which the teacher achieves by gaining increased experience and through self-examination of one's teaching (Glatthorn,1995). The implication here is that gained experience and self-reflection on classroom experiences result to the professional development of the practitioner. Texas Education Agency (1997), states that in order to enhance the professional development of teachers, they should be viewed as learners who need to learn together, mentor and coach each other. Hunzicker (2010), suggests that in order to make teachers development relevant, authentic and sustainable, it should address their specific needs and concerns. Judging by this, it clearly indicates that the professional development of teacher trainers should be based on their needs. From the basis of this it is obvious that for teacher trainers to grow in their career and also enhance the learning process of their learners, they need to participate in professional development activities. Therefore this paper aims at appreciating the range of professional development activities and assessing the impact they have on the teacher trainers as well as identifies the gaps and needs to the teacher trainers for a more effective professional training in the Higher Teacher Training College Bambili.

\subsection{Research Questions}

- Which activities have teacher trainers of HTTC Bambili undertaken within the past two years to enhance their professional development?

- What degree of impact do the professional development activities have on the teacher trainers?

- What are the Professional development needs of teacher trainers and to what extent do they have such needs?

\section{Methodology}

A case study design was used in this study. There are teacher training colleges in Cameroon training teachers for nursery/primary schools, secondary and high schools for both general and technical education, but this research focused on HTTC Bambili because I wanted to have an in depth knowledge on what has been put in place to enhance the professional development and needs of teacher trainers. The sampling technique used for the study was a convenient sample technique which allowed me to use those who were available at the moment. This technique was used because it was really difficult to know the exact time the lecturers would be on campus since they had diverse teaching periods and research programmes. A total number of 30 teaching staff was selected from a population of 72 permanent teaching staff of HTTC Bambili, 6 with a Masters Degree and 24 with a $\mathrm{PhD}$ with little or no background training in teaching. The instruments used for data collection was a questionnaire which was extracted from the Teaching and Learning International Survey Teachers' Questionnaire (TALIS) which focused on the professional development programmes that participant took part in within the last two years and the level of impact those activities had on them. The instrument also measured the extent to which the participants had need for knowledge on teaching 
methods, contents of their specific subject areas, skills, assessment of students, classroom management and counselling. The instrument was administered using the self delivery technique (SDT). The consent of the participants was sought and only those who were willing filled the copies of the questionnaire. The copies of the questionnaire were distributed to the participants in their various departmental offices. Some filled them on the spot while others took two days to complete. All the 30 copies of the questionnaire given out were completed and returned. The results were analysed using descriptive statistic specifically percentages and presented in tables.

\section{FINDINGS}

The findings revealed that teacher trainers exploited diverse professional development activities.

\subsection{Formal Professional Development Activities}

Table 1 shows the professional development activities the respondents participated in and the impact those activities had on their professional development.

Table1: Participation of teacher trainers in professional development activities and the extent to which such activities impact their development as teachers

\begin{tabular}{|l|l|l|l|l|l|l|}
\hline Item & Participation & \multicolumn{2}{|l|}{ Impact } & \multicolumn{2}{l|}{$\begin{array}{l}\text { Large } \\
\text { Impact }\end{array}$} \\
\cline { 2 - 7 } & Yes & No & No Impact & $\begin{array}{l}\text { Small } \\
\text { Impact }\end{array}$ & & \\
\hline $\begin{array}{l}\text { Seminar and workshops on } \\
\text { subject matter, methods and/or } \\
\text { other education related topics) }\end{array}$ & $29(96.7 \%)$ & $1(3.3 \%)$ & $1(3.4 \%)$ & $3(10.3 \%)$ & $17((58.6 \%)$ & $8(27.6 \%)$ \\
\hline $\begin{array}{l}\text { Observation visits to other } \\
\text { classes/departments/schools }\end{array}$ & $19(63 \%)$ & $11(36.7 \%)$ & $13(68.4 \%)$ & $3(15.8 \%)$ & $2(10.5 \%)$ & $1(5.3 \%)$ \\
\hline $\begin{array}{l}\text { Participation in a network of } \\
\text { lecturers formed for research }\end{array}$ & $18(60 \%)$ & $12(40 \%)$ & $09(50 \%)$ & $03(16.7 \%)$ & $2(11.1 \%)$ & $4(22.2 \%)$ \\
\hline $\begin{array}{l}\text { Individuals research on topics } \\
\text { of interest to the teaching } \\
\text { profession }\end{array}$ & $26(86.7 \%)$ & $4(13.3 \%)$ & $6(23.1 \%)$ & $5(19.2 \%)$ & $4(15.4 \%)$ & $11(42.3 \%)$ \\
\hline $\begin{array}{l}\text { Collaborative research on topics } \\
\text { related to the teaching } \\
\text { profession }\end{array}$ & $20(66.7 \%)$ & $10(33.3 \%)$ & $4(20 \%)$ & $1(5 \%)$ & $7(35 \%)$ & $08(40 \%)$ \\
\hline $\begin{array}{l}\text { Mentoring and teaching } \\
\text { practice observation as part of } \\
\text { formal school arrangement }\end{array}$ & $28(93.3 \%)$ & $2(6.7 \%)$ & $2(7.1 \%)$ & $3(10.7 \%)$ & $8(28.6 \%)$ & $14(50 \%)$ \\
\hline
\end{tabular}

The results on table 1 show that majority (96.7\%) of teacher trainers accepted that they participated in seminars and workshops which were based on their subject matter, methods and other education related topics. Out of the 29 participants who attended seminars and workshops, $13.7 \%$ attested that the programmes had little or no impact on them. A greater number of them (58.6\%) said that the programmes had moderate impact on them while some (26.7\%) said these programmes had a large impact on their professional development. Participant were also asked whether they carried out any observation visits to other classes, departments or schools, most $(63 \%)$ of them accepted while minority $(36.7 \%)$ said they did not have such visits. When asked the extent to which observation visits had an impact on them, majority (68.4\%) said observations made no impact on them, $15.8 \%$ said it had small impact, $10.5 \%$ said moderate impact and $5.3 \%$ said observation visit to other classes/departments/schools had a large impact on them. From the responses of the participants, it can be observed that observation visit had little significance as far as the professional development of teacher trainers of HTTC Bambili was concerned.

More so, majority (60\%) of them accepted that they participated in a network of lecturers formed for research purposes, while $40 \%$ did not. when asked the impact it had on them half (50\%) of those who participated in the network said it had no impact on them, 13.3\% said it had small impact, $11.1 \%$ said participation in the network of lecturers/teachers had a moderate impact on them while some (22.2\%) said it had a large impact on them. Based on individual research on topics related to the teaching profession, majority $(86.7 \%)$ of the respondents accepted that they participated while a few of them (13.3\%) did not. As far as the impact of individual research was concerned, a few of them $(23.1 \%)$ 
said it had no impact on them, $19.2 \%$ said the impact was little, while $15.4 \%$ and 42.3 said individual research on topics of interest to the teaching profession had a moderate and a large impact on them respectively. Still on research, majority (66.7\%) of the respondents accepted that they carried out collaborative research on topics related to the teaching profession while 33.3\% did not carry out such research. Among those who carried out collaborative research, a few $(20 \%)$ of them said it had no impact on their professional development, 5\% said small impact, while 35\% and $40 \%$ said collaborative research had moderate and large impact on their professional development respectively. This implies that both individual and collaborative research are imperative in enhancing teacher educators professional development.

The respondents were also asked whether they participated in mentoring and teaching practice observation as part of formal school arrangement. Majority (93.3\%) of the respondents accepted that they participated in those activities. Out of the number of those who monitored and observed teaching practice, a few $(7.1 \%)$ said those activities had no impact on them, some $(10.7 \%)$ said the activities had little impact, others (28.6\%) said it had moderate impact and the majority (50\%) of them said mentoring and teaching practice observation as part of formal school arrangements had a large impact on their professional development.

In order to have an idea on how frequent the teacher trainers were involved in professional development activities, they were asked to indicate the number of days they participated in such activities within the last two years. See table 2 .

Table2: Frequency distribution of the number of days of professional development programmes attended by each respondents during the last two years

\begin{tabular}{|l|l|l|l|l|l|}
\hline \multicolumn{2}{|c|}{ Frequency } & \multicolumn{1}{c|}{ Percent } & \multicolumn{1}{c|}{ Valid Percent } & Cumulative Percent \\
\hline Valid & 2.00 & 6 & 20.0 & 20.0 & 20.0 \\
\cline { 2 - 6 } & 3.00 & 2 & 6.7 & 6.7 & 26.7 \\
\cline { 2 - 6 } & 4.00 & 4 & 13.3 & 13.3 & 40.0 \\
\cline { 2 - 6 } & 5.00 & 1 & 3.3 & 3.3 & 43.3 \\
\cline { 2 - 6 } & 6.00 & 5 & 16.7 & 16.7 & 60.0 \\
\cline { 2 - 6 } & 7.00 & 1 & 3.3 & 3.3 & 63.3 \\
\cline { 2 - 6 } & 8.00 & 2 & 6.7 & 6.7 & 70.0 \\
\cline { 2 - 6 } & 9.00 & 2 & 6.7 & 6.7 & 76.7 \\
\cline { 2 - 6 } & 10.00 & 2 & 6.7 & 6.7 & 83.3 \\
\cline { 2 - 6 } & 12.00 & 2 & 6.7 & 6.7 & 90.0 \\
\cline { 2 - 6 } & 14.00 & 1 & 3.3 & 3.3 & 93.3 \\
\cline { 2 - 6 } & 20.00 & 1 & 3.3 & 3.3 & 100.0 \\
\cline { 2 - 6 } & 22.00 & 1 & 3.3 & 100.0 & \\
\cline { 2 - 6 } & Total & 30 & 100.0 & & \\
\hline
\end{tabular}

Table 2 shows that a slight majority of the respondents attended professional development programmes between 2 and 6 days during the last two years. It is clear that 6 of the respondents attended the professional development programme for 2 days, 2 attended for 3 days, 4 attended for 4 days, 1 for 5 days, and 5 attended for 6 days. This means that out of the 30 respondents 18 (60\%) attended professional programmes between 2 and 6 days. The rest of participants attended programmes between 7 and 14 days. The results indicate that 1 attended the professional development programme for 7days, 2 each for 8, 9, 10, 12 days, and 1each for 14, 20 and 22days within the last two years. These results show that teacher trainers were aware of the fact that professional development programmes are necessary for their careers and need to always participate in such activities although attending just two professional development programmes within two years does not really sound encouraging for the teacher trainers.

\subsection{Less Formal Professional Development Programmes}

Professional development programmes are not limited to formal activities, therefore it was necessary to look at the less formal professional activities carried out by teacher educators of HTTC Bambili and the extent to which such activities impact their professional development as teachers. These results are presented on table 4 . 
Professional Development of Teacher Trainers in the Higher Teacher Training College Bambili (Cameroon)

Table4: Participation of respondents in less formal professional development activities during the last two years

\begin{tabular}{|l|l|l|l|l|l|l|}
\hline \multicolumn{1}{|c|}{ Item } & \multicolumn{2}{|c|}{ Participation } & \multicolumn{4}{c|}{ Impact } \\
\cline { 2 - 6 } & Yes & No & No Impact & $\begin{array}{l}\text { Small } \\
\text { Impact }\end{array}$ & $\begin{array}{l}\text { Moderate } \\
\text { Impact }\end{array}$ & $\begin{array}{l}\text { Large } \\
\text { Impact }\end{array}$ \\
\hline $\begin{array}{l}\text { Reading professional literature } \\
\text { (e.g. articles, papers, thesis, } \\
\text { book chapters) }\end{array}$ & $25(83.3 \%)$ & $5(16.7 \%)$ & $2(8 \%)$ & $4(16 \%)$ & $11(44 \%)$ & $8(32 \%)$ \\
\hline $\begin{array}{l}\text { Engaging in informal dialogue } \\
\text { with your colleagues }\end{array}$ & $7(23.3 \%)$ & $23(76.7 \%)$ & $2(28.57 \%)$ & $0(00 \%)$ & $2(28.57 \%)$ & $3(42.86 \%)$ \\
\hline
\end{tabular}

Table 4 indicates that majority $(83.3 \%)$ of the respondents accepted that they used professional literatures especially scientific articles, empirical papers, and thesis which could enhance their professional development as teacher trainers. On the other hand, $16.7 \%$ indicated that they did not read any professional literature during the last two years. Some advanced reasons that they did not consider themselves as teacher trainers since they were teaching classical subjects like History, Geography and Geology. For those who read professional literature, $44 \%$ and $32 \%$ said it had moderate and large impact on their professional development respectively while $16 \%$ and $8 \%$ said it had small and no impact on them respectively. This indicate that when teacher trainers read professional literatures from any source it helps to improve their knowledge and skills in the teaching profession in one way or the other.

Another dimension of less formal professional programme was on engagement in informal dialogue with colleagues. The results prove that, an over-whelming majority $(76.7 \%)$ of the respondents indicated that they did not engage in informal dialogue with their colleagues on issues related to the teaching-learning process. Only a few of them (23.3\%) accepted that they engaged in informal dialogues with colleagues. For those who engaged in informal dialogue with colleagues, $28.57 \%$ and $42.86 \%$ said it had moderate and high impact on them respectively while $28.57 \%$ said it had no impact on them. The results indicate that teacher trainers in HTTC Bambili hardly engage in informal dialogue on issues which could enhance their professional development.

\subsection{Professional Needs of Teacher Educators}

It was also necessary to find out from the teacher educations whether they had needs as far as the subject matter, pedagogical and professional knowledge were concerned. Table 5 shows the extent to which they had such needs.

Table5: Professional development needs and the extent to which participants had such needs in each of the areas listed

\begin{tabular}{|l|l|l|l|l|}
\hline \multicolumn{1}{|c|}{ Item } & \multicolumn{1}{|c|}{ No Need } & $\begin{array}{c}\text { Low Level } \\
\text { Need }\end{array}$ & $\begin{array}{c}\text { Moderate } \\
\text { Level Need }\end{array}$ & $\begin{array}{c}\text { High Level } \\
\text { Need }\end{array}$ \\
\hline $\begin{array}{l}\text { Content knowledge and understanding of the } \\
\text { main subject field }\end{array}$ & $6(20 \%)$ & $6(20 \%)$ & $9(30 \%)$ & $9(30 \%)$ \\
\hline Diverse instructional (teaching) methods & $5(16.7 \%)$ & $2(6.7 \%)$ & $12(40 \%)$ & $11(36.7 \%)$ \\
\hline Student assessment practices & $6(20 \%)$ & $4(13.3 \%)$ & $11(36.7 \%)$ & $9(30 \%)$ \\
\hline Classroom management approaches/skills & $8(26.7 \%)$ & $8(26.7 \%)$ & $11(36.7 \%)$ & $3(10 \%)$ \\
\hline $\begin{array}{l}\text { Knowledge of learners and enhancement of } \\
\text { learning }\end{array}$ & $6(20 \%)$ & $4(13.3 \%)$ & $11(36.7 \%)$ & $9(30 \%)$ \\
\hline $\begin{array}{l}\text { ICT skills for teaching and other instructional } \\
\text { teaching materials }\end{array}$ & $5(16.7 \%)$ & $9(30 \%)$ & $7(23.3 \%)$ & $9(30 \%)$ \\
\hline Teaching students with special learning needs & $4(13.3 \%)$ & $4(13.3 \%)$ & $4(13.3 \%)$ & $18(60 \%)$ \\
\hline Student discipline and behavioural problems & $5(16.7 \%)$ & $4(13.3 \%)$ & $11(36.7 \%)$ & $10(33.3 \%)$ \\
\hline Student counselling & $4(13.3 \%)$ & $5(16.7 \%)$ & $10(33.3 \%)$ & $11(36.7 \%)$ \\
\hline
\end{tabular}

Participants were asked whether they needed content knowledge and understanding of their main subject field, majority of them (80\%) accepted that they needed more knowledge on the contents of their main subjects they were teaching so as to update their present knowledge and teach effectively, $20 \%$ said they did not need any additional knowledge on their subject area. As far as diverse instructional methods were concerned, majority $(83.3 \%)$ of the respondents overwhelmingly accepted that they needed more knowledge and skills on how to use diverse instructional methods while a few 
of them $(16.7 \%)$ said they did not need more knowledge on that. Out of the 25 respondents who accepted they needed more knowledge on instructional method, 20 indicated that their need was very high. Also majority (93.3\%) of the respondents attested that they needed more knowledge on students' assessment practices although most of them indicated moderate need.

On the issue of classroom management approaches/skills, $73.3 \%$ indicated that they needed more knowledge and skills on how to effectively manage their classrooms. From my conversation with some of the respondents, it was realised that some of the respondents thought classroom management was limited to discipline (an aspect of the authoritarian classroom management approach). Some (26.7\%) respondents stated that they did not need to improve on their knowledge and skills on classroom management. This was on grounds that they had been teaching for long and had gained enough experiences on this aspect. Participants were also asked whether they needed any professional development programmes on knowledge of learners and enhancement of learning. An overwhelming majority $(93.3 \%)$ confirmed that they highly needed programmes on those aspects. From the informal conversation with some of the respondents, most of them explained that they put in their best in teaching but some students still could not perform well, therefore they believed that if they could have more professional development programmes which will add their knowledge of learners and enhancement of learning, it would go a long way to enhance their teaching aptitudes. As far as the Information and Communication Technologies (ICT) skills for teaching and other instructional teaching materials were concerned, majority $(83.3 \%)$ of the participants accepted that they needed professional development programmes on these materials although most of them indicated low and moderate level of needs. When questioned on why they indicated low level of needs some said they have been using these materials in teaching and needed just to update their skills especially the ICTs. Participants were also asked whether they needed more knowledge on teaching students with special learning needs and an overwhelming majority $(96.7 \%)$ confirmed that they needed the knowledge. Out the 29 that accepted, 20 of them indicated that they highly needed professional development programmes on this aspect. When asked why they strongly needed programmes on teaching learners with special needs, some said they needed the knowledge so that they could become more inclusive in their teaching since inclusive education is gradually gaining grounds in Cameroon schools and colleges.

The respondents were also asked whether they needed knowledge and skills on handling students' behavioural problems and discipline, majority (83.3\%) accepted although they were variations on their level of needs. It was realised that out of the 25 respondents who accepted, 4 indicated low need while 11 and 10 indicated they had moderate and high levels of needs respectively as far as discipline and handling of behavioural problems were concerned. Majority (86.7\%) of the respondents also indicated that they needed knowledge of counselling as teacher educators. According to them it is necessary to have basic knowledge of counselling which could help them effectively handle some socio-emotional and learning problems during the teaching learning transaction.

After looking at the professional development activities and professional needs of teacher trainers at HTTC Bambili, it was necessary to find out whether they needed more professional development programmes or not. The responses are summarized on table 6 .

Table6: Need for more professional development programmes

\begin{tabular}{|l|l|l|l|l|l|}
\hline \multicolumn{2}{|c|}{ Frequency } & \multicolumn{1}{|c|}{ Percent } & \multicolumn{1}{c|}{ Valid Percent } & Cumulative Percent \\
\hline \multirow{3}{*}{ Valid } & NO & 4 & 13.3 & 13.3 & 13.3 \\
\cline { 2 - 6 } & YES & 26 & 86.7 & 86.7 & 100.0 \\
\cline { 2 - 6 } & Total & 30 & 100.0 & 100.0 & \\
\hline
\end{tabular}

The results on table 6 shows that majority, $(86.7 \%)$ of the respondents would have loved to participate in more professional programmes than they did while a few (13.3\%) persons indicated that they did not want to participate in more programmes. According to them the programmes they participated in within the last two years were enough for their professional development.

\section{DISCUSSION}

The teacher trainers participated in seminars, conferences and workshops within the last two years and these programmes impacted them in varied ways. This is very interesting because in order to enhance 
professional development, it is necessary to attend conferences, seminars, workshops to improve on or gain more knowledge on subject matter, teaching techniques, skills and assessment. This is in line with Musaazi (1982) who emphasizes that in order to enhance the professional development of teachers, they should take part in workshops, seminars, refresher courses, exchange teaching, professional writing, staff meetings and post graduate studies. If teacher educators do not attend these programmes especially those who did not take any courses in education, it becomes very difficult to teach effectively. It was also realised that some teacher trainers participated in collaborative research and networking. This is very important in any profession. Collaborative research and networking help in sharing ideas, skills which are very vital in professional development. This converges with the conclusions of Michael (1993) and Texas Education Agency (1997), which state that collaboration is one of the great capacities in enhancing professional development of teachers. Networking helps the teacher educators to gain more knowledge on cross-cultural issues which can enhance the training of teachers.

Although majority of the teacher trainers indicated that they participated in activities which enhanced their professional development, most of them also indicated that they needed more knowledge and skills on diverse teaching methods, student assessment, classroom management approaches, knowledge of learners, counselling and content knowledge in their respective fields. These needs varied among individuals. Generally the needs of the teacher trainers could be categorised into pedagogical and psychological aspects which are the pivot of the teaching-learning transaction. The findings of this study support the studies of Hill, Rowan \& Ball (2005), and Voss, Kunter \& Baumert (2011) which state that teachers including teacher educators need the pedagogic and psychological knowledge which will help enhance the teaching-learning process. They emphasise that pedagogic knowledge involves knowledge of classroom management, instructional methods and assessment. Knowledge of classroom management helps the trainer to maximize instructional time, discipline and maintain clear directions in lessons. It is necessary for teacher educators to have a mastery and command of various instructional methods and use them appropriately. Nsamenang \& Tchombe, (2011) also support the fact that teachers need to have knowledge on the diverse instructional methods and use them effectively to enhance the learning of all learners. Teacher trainers are looked upon by student teachers as model. If they use the teaching methods effectively, the students will also model them. Teacher trainers need to have knowledge of the different types of assessments techniques, tools, and the purposes of assessment. Psychological knowledge on the other hand includes: learning process, to foster and support individual learning, learning styles, cognitive processes, learning strategies, importance of reinforcement and knowledge of individual student characteristics. It is imperative for teacher trainers to have basic knowledge of some of these concepts as they indicated. In order to equip them with the knowledge and skills required, and enhance professional development, it is necessary for teacher trainers engage in short courses, workshops and seminars to improve on their pedagogic, psychological and contents knowledge.

\section{CONCLUSION}

There is no gain saying that the professional development of teacher trainers is very relevant. In spite of this importance, it is seldom given central consideration. This lacuna occupies a central concern in one of Cameroon's lead teacher training colleges, the Higher Teacher Training College Bambili. If teacher trainers engage regularly in professional development programmes, there is the likelihood for them to gain more knowledge in their subject areas, appropriate skills on pedagogy and psychology. These competences would enhance the teaching -learning transaction and by extension their career development as professionals. It should be noted that the teaching learning transaction has innovative activities almost on daily bases. In order to be versed with such dynamics teacher trainers need to participate in workshops, seminars, short courses, observation of colleagues, collaborative research and others. Professional development is not measured by how teachers feel about it, but by the impact that it has on their practice and more importantly the achievement of the students. Professional development should be regular and should be prioritised by the school administrators. It is necessary to be acquainted with students' problems or get feedbacks from students in relation to the teachinglearning process. This will help the school administrators to know which professional activities to prioritise in order to optimise learning. Teacher trainers are looked upon by student teachers as models, therefore they must strive for more knowledge and skills to maintain this status quo. 


\section{REFERENCES}

[1] Glatthorn, A. (1995). Teacher development. In L.W.Anderson, (Ed.).International encyclopaedia of Teaching and Teacher Education ( $2^{\text {nd }}$ ed.) London: Pergamon Press.

[2] Hill. H, Rowan. B \& Ball. D. (2005). Effects of teachers' mathematical knowledge for teaching on students achievements. American educational research journal 42 (2) 371-406.

[3] Hunzicker, J. (2010). Characteristics of effective Professional Development: a check list.

[4] Michael G. Fullan (1993), The Professional Teacher. Toronto, Volume 50 Number 6, Pages 12-17, Association for Supervision and Curriculum Development.

[5] Morris, D. (2009). Academic staff development. Journal for Academic Development,6(1), 103-112.

[6] Musaazi, J.C.S. (1982). The theory and practice of educational administration. Nigeria: Macmillian Heinemann

[7] Palinscar, A.S. (1998). Social constructivist perspective of teaching and learning. Annual Review of Psychology. Vol. 49,345-375

[8] OECD Teaching and Learning International Survey (TALIS). Retrieve from www.oecd.org on the $20^{\text {th }}$ November 2018.

[9] Tchombe, T. M. S. (2011). Theories of learning. In Nsamenang, A. B., \& Tchombe, T. Handbook of African Educational Theories and Practices: A Generative Teacher Education Curriculum (pp. 177-193). Bamenda: HDRC

[10] Texas Education Agency, (1997). Professional Development for Language Teachers: Implementing the Texas Essential Knowledge and Skills for Languages Other Than English. Southwest Educational Development Laboratory Austin, Texas.

[11] Volbrecht, T. (2003). The Story of South African academic development on international perspectives: have we lost the plot? South African Journal of Higher Education, 12(2), 110-117.

[12] Voss, T, Kunter, M. \& Baumert, J. (2011). Assessing teacher candidates' general pedagogic /psychological knowledge. Test construction and validation. Journal of Educational Psychology, Vol 103(4), 952-969

\section{AUTHOR'S BIOGRAPHY}

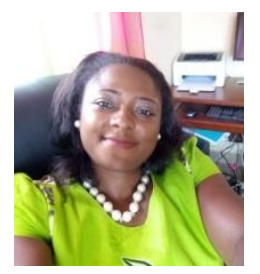

Dr. Lilian F. Wiysahnyuy is currently the chair of the Department of Guidance and Counselling, and lecturer in the Department of science of Education in the Higher Teacher Training College, The University of Bamenda in Cameroon. She is a member of the International Society for the Study of Behavioural Development (ISSBD) and Cameroon Psychology Association (CPA). Her teaching and research focus on psychology of learning, developmental psychology, early childhood development and education, school counselling and educational research methods.

Citation: Lilian F. Wiysahnyuy. "Professional Development of Teacher Trainers in the Higher Teacher Training College Bambili (Cameroon)". International Journal of Humanities Social Sciences and Education (IJHSSE), vol. 6, no.7, 2019, pp. 55-62. doi: http://dx.doi.org/10.20431/2349-0381.0607006.

Copyright: () 2019 Authors. This is an open-access article distributed under the terms of the Creative Commons Attribution License, which permits unrestricted use, distribution, and reproduction in any medium, provided the original author and source are credited. 